\title{
IMPLEMENTASI PENDIDIKAN AGAMA DAN KE AGAMAAN PASCA KONFLIK DI DAERAH MAMBI SULAWESI BARAT
}

Oleh: Rosdiana

\begin{abstract}
Abstrack
This research aims to describe the implication of social conflict to education of religion (formal and informal) implementation. This was conducted at Mambi, West Sulawesi. Data was collected by depth interview and observation.

This research indicates that social conflict atAralle, Tabulahan, Mambi during 2002-2005 had give impact the some education of religion implementation, such as (a) system of school administration was disfunction, (b) number of teachers and students was decrease. Most of them went out to another place. Nevertheless, this conflict didn't influence to the learning process of religion education and religion activity.
\end{abstract}

Key word: implementation, education, religion, conflict

\section{PENDAHULUAN}

\footnotetext{
- i ra globalisasi membawa masyarakat kepada serangkaian tantangan baru berupa pemikiran/faham yang berdampak luas terhadap hidup dan - 1 _- r/kehidupan umat manusia tidak terkecuali pendidikan agama dan keagamaan. Oleh sebab itu, tampaknya pendidikan agama dan keagamaan melalui institusi dan media, keberhasilannya masih dipertanyakan akibat dari berbagai ketegangan yang terjadi dalam kehidupan masyarakat. Sejak tahun 1996 peristiwa ketegangan berupa konflik, kerusuhan, prasangka, sterotif dan kesenjangan sosial terjadi dibeberapa daerah, antara lain seperti Maluku, Poso dan Mataram (Nusa Tenggara Barat) bahkan jauh sebelumnya terjadi pula di Aceh. Ketegangan tersebut baik dalam segala kecil, besar, bernuansa agama,
} 
suku maupun golongan telah membawa korban harta, jiwa, kehormatan dan berpengaruh pada berbagai tatanan hidup masyarakat dan institusi sosial, antara lain institusi pendidikan formal maupun non formal.

Pada saat ini terjadi ketimpangan proses sosialisasi tidak terhindarkan, dampak dari ketegangan sosial tersebutjuga dirasakan oleh pendidikan agama dan keagamaan. Pendidikan agama dan keagamaan tersebut tidak menghidupkan pendidikan multikultural yang baik, bahkan cenderung berlawanan. Pendidikan agama dan keagamaan disuatu lembaga pendidikan terkadang masih menafikan pendidikan dan hak hidup agama lain, hal ini terjadi dikalangan mayoritas maupun yang minoritas. Semangat pendidikan agama dan keagamaan seperti ini berlawanan secara fundamental dengan semangat pendidikan multikultural dan melemahkan kesatuan dan persatuan bangsa.

Indonesia adalah Negara demokrasi melindungi Hak Asasi Manusia (HAM), melindungi hak hidup dan kepercayaan bagi masyarakatnya maka segala sesuatu yang hidup dan berkembang di Indonesia semuanya diayomi. Pemerintah terutama pemerintah daerah memiliki kewenangan yang sangat penting bagi suatu daerah di dalam menetapkan peraturan daerah sepanjang tidak bertentangan dengan kepentingan umum dan peraturan dan perundang-undangan yang berlaku termasuk peraturan yang berkenaan dengan pendidikan agama dan keagamaan.

Berdasarkan latar belakang tersebut, maka permasalahan yang diajukan dalam penelitian ini adalah: Bagaimana dampak konflik sosial terhadap implementasi pendidikan agama dan keagamaan pasca konflik di Kecamatan Mambi provinsi Sulawesi Barat, Bagaimana kebijakan pemerintah terhadap pendidikan agama dan keagamaan pasca konflik di Kecamatan Mambi provinsi Sulawesi Barat, dan Bagaimana implementasi pendidikan agama dan keagamaan pasca konflik di Kecamatan Mambi provinsi Sulawesi Barat.

Dari penelitian ini diharapkan suatu rumusan sebagai bahan masukan bagi penentu kebijakan (pemerintah) dalam rangka pengambilan keputusan tentang pembangunan terutama pembangunan di bidang agama.

Daerah yang menjadi lokasi penelitian adalah kecamatan Mambi Propinsi Sulawesi Barat. Penelitian ini bersifat kualitatif. Teknik pengumpulan data menggunakan wawancara mendalam dan obesrvasi. Sumber data adalah pemerintah daerah, yaitu Kesbang, Departemen Agama (Kanwil Departemen Agama), Lembaga Pendidikan (sekolah), Kepala Sekolah, pendidik dan tenaga administrasi, tokoh agama, dan tokoh masyarakat. 


\section{HASIL PENELITIAN DAN PEMBAHASAN}

\section{A. Profil Konflik}

Konflik yang terjadi di kecamatan Aralle, Tabulahan, dan Mambi dipicu oleh pro-kontra penggabungan wilayah tiga kecamatan tersebut ke kabupaten Mamasa provinsi Sulawesi Barat. Terbitnya Undang-undang No 11 tahun 2002 tentang pembentukan kebupaten Mamasa dan Palopo, yang menetapkan baliwa 10 kecamatan di wilayah kabupaten Mamasa berasal dari sebagian wilayah kabupaten Polewali Mamasa, 10 kecamatan tersebut diantaranya: Kecamatan Tabulahan, Mamasa, Tabang, Pana, Mesawa, Sumarorong, Sesenapadang, Tanduk Kalua, Mambi, dan kecamatan Aralle dengan luas wilayah secara keseluruhan $3.0005,88 \mathrm{~km}^{2}$.

Sumber permasalahan sesungguhnya terletak pada tiga kecamatan Aralle, Mambi, dan Tabulahan. Penduduk yang pro Mamasa di tiga kecamatan tersebut ingin tetap bergabung ke wilayah Mamasa sementara penduduk yang kontra tetap ingin bergabung ke wilayah Polman, masing-masing penduduk yang pro dan kontra cenderung mempertimbangkan faktor Historis dan Budaya. Kelompok masyarakat Aralle, Tabulahan, dan Mambi menolak bergabung ke wilayah kabuapetn Mamasa karena umumnya berasal dari etnik Mandar yang beragama Islam, sementara kelompok masyarakat yang pro-Mamasa umumnya berasal dari etnik Mamasa yang secara budaya dan adat lebih dekat dengan suku Toraja dan beragama Kristen/Katolik.

Pada masa lalu, orang Mamasa dan Mambi berusaha memelihara kerukunan diantara mereka. Misalnya, adanya perjanjian To Pao yang isinya bertujuan agar penduduk kedua daerah tersebut senantiasa hidup berdampingan secara damai. Selain itu, perkawinan beda agama atau perkawinan yang didahului dengan konversi agama salah satu pihak dari calon pengantin. sangatjarang terjadi di wilayah Mambi dan sekitarnya. Salah satu pertimbangannya, agarhal semacam itu tidak menimbulkan konflik. (Arraiyyah, 2005:35).

Sebelum terjadi konflik pada tanggal 20 Mei 2000 tokoh-tokoh politik dari Polewali dan Mamasa mengambil ini inisiatif dan menjembatani pertemuan antar kedua belah pihak yakni pihak yang menginginkan setuju terhadap pemekaran Mamasa dan pihak yang tetap ingin bergabung ke Poimas. Hasil dari pertemuan tersebut yang disepakati oleh kedua belah pihak tertuang dalam "Deklarasi Matakali" dan ditanda tangani oleh kedua belah pihak yakni pihak penuntut pembentukan kabupaten Mamasa dan Ikatan Keluarga Pitu Ulunna Salu. Isi deklarasi Matakali antara lain: 
1. Setuju atas adanya upaya untuk pemekaran kabupaten Polewali Mamasa

2. Wilayah (daerah) yang akan dibentuk itu adalah wilayah eks. Kewedanan Mamasa terkecuali yang masyarakatnya belum-setuju (menolak) untuk pemekaran dan tetap bergabung dengan kabupaten induk (Polmas).

3. Mendukung keputusan DPRD kabupaten Polewali, Mamasa, tentang persetujuan pemekaran kabupaten Polewali Mamasa, dan masing-masing bertanggungjawab atas hal-hal yang mungkin timbul sebelum dan sesudah pengambilan keputusan DPRD.

4. Bertekad bulat untuk tetap memperkokoh persatuan dan kesatuan baik secara kekeluargaan maupun secara sosial budaya.

5. Sejak lahirnya kesepakatan Matakali ini, kedua belah pihak sepakat untuk tidak memobilisasi massa dan tidak ada lagi penyampaian aspirasi yang berhubungan penolakan dan penuntutan pembentukan kabupaten eks. Kewedanan Mamasa. (Idham, 2008).

Konflik identitas yang terjadi di kecamatan Aralle, Tabulahan dan Mambi, hendaknya menjadi pelajaran berbagai pihak khususnya pihak pemerintah dalam mengembangkan otonomi daerah, kedepan konflik horizontal yang berdimensi pemekaran wilayah, masih akan terus terjadi, berbagai faktor bisa saja dapat menjadi penyebab bila tidak memperhatikan kecenderungan yang berkembang di tengah masyarakat, diantaranya faktor, etnis, budaya dan agama.

\section{B. I)anipak konflik terhadap pendidikan agama dan keagamaan.}

Beberapa dampak akibat konflik yang terjadi di kecamatan Mambi yang berakibat pada dunia pendidikan maupun aktivitas keagamaan:

\section{Sistem Pelaksanaan Administrasi Pendidikan}

Secara umum gambaran yang ditimbulkan akibat konflik pada aspek pendidikan agama dan keagamaan secara urgen terdapat pada bidang-bidang tertentu. Bidang yang paling krusial yang dirasakan masyarakat pada umumnya adalah ketidakjelasan pemerintahan pada tingkat kabupaten, terutama penentuan wilayah-wiliyah kecamatan khusus wilayah kecamatan Aralle, Tabulahan dan Mambi. Hal ini turut berdampak pada aktivitas pendidikan di wilayah kecamatan Mambi baik pendidikan yang bernaung di bawah DIKNAS maupun DEPAG. Fungsi dan peran yang di tetapkan pada tingkat kabupaten untuk DIKNAS masih berada di bawah naungan DIKNAS kabupaten lama yakni DIKNAS Kabupaten Polewali Mandar. Sementara untuk DEPAG diambilalih oleh 
KANWIL provinsi tanpa Kandepag di tingkat kabupaten. Ini merupakan salah satu dampak yang paling mengganggu dunia pendidikan di kecamatan Mambi, Ini lebih lanjut terkait dengan segala bentuk dan aktivitas guru-guru dalam wilayah ini. Berbagai kasus bermunculan seperti pemberian tunjangan fungsional kepada guru-guru terutama guru honorer, sertifikasi guru, sistem penggajian, dan lainlain.

\section{Berkurangnya Guru-guru}

Dampak lain yang ditimbulkan dan sangat sangat mengganggu aktivitas belajar mengajar adalah berkurangnya guru-guru pada sekolah-sekolah umum pada semua tingkatan (SD, SMP, dan SMA) dimana guru-guru ini berada di bawah naungan DIKNAS. Guru-guru tersebut sebagian merupakan guru-guru yang pro kepada pemekaran dan rata-rata menganut agama kristen dan sebagaian lagi merupakan guru-guru yang pindah ke sekolah lain pada saat pengungsian, kepergian guru-guru tersebut meninggalkan berbagai masalah terutama menghambat proses pembelajaran.

Keadaan guru di sekolah-sekolah terutama yang masih berstatus honorer, mereka bahkan mengajar tanpa pamrih. Mereka sama sekali tidak mendapat dana tunjangan mengajar, Secara administrasi seharusnya melaporkan guru honorer tersebut ke DIKNAS kabupten, tetapi untuk wilayah kecamatan Mambi hal itu tidak di laporkan ke kabupaten Mamasa disebabkan pro konta yang terjadi pada masyarakat. Jadi kecamatan Mambi kehilangan induk dalam pelaporan ke tingkat atas. Bagaimanapun juga kesejahteraan guru cukup mempengaruhi proses belajar mengajar di sekolah, tentu saja yangjadi korban adalah anak didik. Baik mata pelajaran umum maupun mata pelajaran agama.

Berbeda halnya guru-guru pada lingkup Departemen Agama, tidak mengalami pengurangan yang berarti pada sekolah-sekolah. Hal ini di karenakan dominasi guru-guru di bawah naungan Departemen Agama adalah beragama Islam.

Fungsi dan posisi guru-guru, di daerah konflik sangat sentral dan strategis. Karena mereka berperan untuk menghilangkan trauma dan dendam akibat konflik. Guru-guru di daerah konflik harus mampu menanamkan wawasan multikulturalisme pada anak didiknya. Sehingga siswa mampu saling memahami setiap perbedaan dan menghargai tradisi masing-masing kelompok.

Pendidikan multikultural adalah proses penanaman cara hidup menghormati, tulus, dan toleran terhadap keanekaragaman budaya yang hidup di tengah-tengah 
masyarakat. Dengan pendidikan multikultural, diharapkan adanya kekenyalan dan kelenturan mental dalam menghadapi benturan konflik sosial. Sehingga persatuan bangsa tidak mudah patah dan retak.

Menurut Abd. Arifin S.Ag (Kepala sekolah MTs DDI 0017 Mambi) pendidikan multikultural hendaknya lebih dimaksimalkan kepada selumh lapisan masyarakat, konflik yang terjadi di wilayah Aralle, Tabulahan dan Mambi hendaknya memberi catatan merah buat kita semua. Untuk selanjutnya dalam menata dunia pendidikan sangat dirasakan pentingnya keselarasan antara pemahaman ajaran agama dan pengalaman di masyarakat. Upaya pemberdayaan lembaga pendidikan dan lembaga keagamaan harus dilakukan dengan cara memediasi agar interaksi sosial di berbagai kalangan masyarakat berbeda agama tetap terjaga dengan baik. Upaya-upaya yang dapat dilakukan diantaranya melalui pertemuan, dialog, dan kerjasama untuk mengembangkan vvawasan multikultural guna memberi wawasan plural sosial dan penghargaan pada keberagamaan, terutama pada anak didik.

Implementasi wawasan multikutural oleh guru-guru lebih ditekankan lagi sebagai upaya dalam membuka wawasan siswa-siswa untuk lebih terbuka akan perbedaan, ini merupakan salah satu upaya dalam mencegah terjadinya konflikkonflik di masa yang akan datang.

\section{Berkurangnya Siswa-siswa}

Khususnya pada sekolah umum dalam hal ini SMA 1 Mambi turut merasakan berkurangnyajumlah siswa pasca konflik, jumlah keseluruhan siswa untuk tahun ajaran 2007-2008 adalah sebanyak 230 siswa dan bila dibandingkan denganjumlah siswa sebelum konflik berkisar +400 siswa. Data yang akurat siswa sebelum konflik tersebut agak sulit di temukan karena data-data sekolah banyak yang hilang ketika konflik terjadi.

Ketika konflik terjadi siswa-siswa masing-masing berusaha menyelamatkan diri ke hutan, ke daerah Majene, Mamuju, Polman, Enrekang adajuga pindah ke Mamasa bahkan ke Makassar. Adajuga yang tidak lagi kembali ke sekolah setelah konflik, karena sudah resmi pindah dari sekolah, terutama yang beragama Nasrani.

Setelah konflik terjadi aktifitas keagamaan di sekolah belum pulih sepenuhnya sebagaimana keadaan sebelum konflik, hal ini terjadi karena selain berkurangnya siswa yang berdampak kurang meriahnya acara, adajuga masih merasa trauma dengan tragedi yang terjadi. Sehingga kadang suara sepeda motor saja yang 
agak besar, para siswa sudah kaget dan berlari keluar dari ruang kelas. Bahkan ada beberapa siswa yang tidak aktif kembali ke sekolah, kadang datang dan kadang menghilang, ini disebabkan bila orang tua mereka mendengar berita atau isu akan terjadi lagi kerusuhan, mereka cepat membawa keluarga mereka mengungsi ke daerah yang dianggap aman.

Tidak terkecuali pada MI DDI Tapalinna oleh kepala sekolah Hadirah A. Ma mengungkapkan bahwa "pasca konflik kondisi sekolah amat mengalami penurunan dari segijumlah siswa. Pada saat ini MI DDI Tapalinna hanya memiliki jumlah siswa secara keselurahan 75 orang, hal ini berkurang bila dibandingkan dengan kondisi sebelum konflik. Penurunan jumlah siswa terus terjadi dari tahunketahun pasca konflik".

Penambahan jumlah siswa yang belajar terjadi di MI DDI Saluaho. Oleh Dra. Suhuria (kepala sekolah) mengungkapkan bahwa "dengan keberadaan MI DDI Saluaho sejak tahun 1976 turut memberi arti dunia pendidikan yang ada di kecamatan Mambi, untuk tahun ajaran 2007-2008 jumlah siswa yang belajar di sekolah kami adalah sekitar 96 siswa yang terdaftar. Jumlah ini terkadang timbul tenggelam artinya siswa yang belajar terkadang tidak mengikuti proses belajar mengajar dikarena mengikuti orang tua yang mengungsi terkadang kembali dan terkadang pergi. Dan sebagian siswajuga dititipkan pada sekolahsekolah di daerah pengungsian.

\section{Terjadinya Arus Pengungsian}

Seperti yang diuraikan di atas, konflik kekerasan yang terjadi masih menyisakan dampak langsung maupun tidak langsung. Dampak langsung masih terdapat pengungsian korban konflik, khususnya anak-anak dan perempuan, di luar wilayah Mambi. Pada desa Rantebulahan dusun Katiloang yang berjumlah sekitar $47 \mathrm{KK}$, sebagian warga/penduduk belum kembali, pada dusun Katiloang belum tampak aktivitas yang berarti, ini juga terlihat pada aktivitas keagamaan penduduk terutama pada masijd dusun tersebut yang tidak berfungsi dan terurus.

Dampak tak langsung dari konflik adalah akibat yang tidak dapat dilihat dengan kasat mata, tapi dirasakan ada, dan mewujud dalam berbagai bentuk gejala sosial. Suasana kecurigaan dan belum terbangunnya kepercayaan antara pihak-pihak yang bertikai tercermin dalam kenyataan segregasi sosial baik berdasarkan agama maupun etnis. Pendek kata, secara umum konflik kekerasan ini telah memperlemah kemampuan masyarakat untuk mendialogkan, memperdebatkan, memperjuangkan dengan cara-cara damai tentang apa yang 
Dalam mengatasi kondisi tersebut, pemerintah Sulawesi Barat terus berupaya untuk mengembangkan dan mejalankan program-program sebagai upaya peningkatan mutu pendidikan, salah satu program yang dikembangkan adalah program Tuntas Wajib Belajar 9 tahun oleh Dinas Pendidikan. Programprogram lain yang turut dikembangkan oleh Dinas Pendidikan adalah pemerataan dan perluasan akses pendidikan (mendirikan SMP terbuka, membuat sistem pendidikan satu atap SD/SMP, rehabilitasi dan pembangunan sekolah dilokasi strategis, kejar paket A dan B, dan pendataan Sistem Informasi Pendidikan Berbasis Masyarakat (SIPBM).

Berangkat dari kondisi di atas akanjelas sekali bahwa eksistensi Pendidikan Agama Islam di madrasah sangatjelas dan dapat dirasakan. Oleh karena itu, dalam rangka meningkatkan dan memperdayaan dan sekaligus pengembangan Pendidikan Islam secara terus menerus. Diantara kebijakan yang dilakukan oleh Departemen Agama dalam pembinaan Bidang Madrasah dan Pendidikan Agama Islam (Mapenda) dapat dilihat sebagai berikut : 1) Pemerataan pendidikan, diarahkan untuk menunjang penuntasan waj ib belajar 9 tahun (Wajar 9 tahun). 2) Peningkatan Mutu Pendidikan diseluruhjenjang pendidikan, baik ditingkat MI maupun MTs dan serta peningkatan kualitas Pendidikan Agama Islam disekolah Umum. 3) Efektifitas dan efisiensi artinya penyelenggaraan pendidikan benar-benar dapat mencapai tujuan pendidikan yang maksimal dengan memanfaatkan biaya yang minimal.

Upaya lain dalam meningkatkan mutu pendidikan hendaknya juga dibarengi peningkatan mutu dan propesionalisme guru. Hal ini disandarkan pada upaya Kelompok Kerja Guru (KKG) pada tingkat MI dan MGMP (Musyawarah Guru Mata Pelajaran) pada tingkat MTs dan MA. Salah satu tujuan yang ingin di capai adalah meningkatkan kemampuan guru menyusun dan merumuskan kurikulum sendiri. Beberapa kegiatan yang dilakukan oleh pihak Kanwil berkaitan dengan pelibatan KKG dan MGMT, antara lain Kanwil Depag telah berkalikali melakukan sosialisasi dan orientasi. Kegiatan-kegiatan terbebut adalah:

1. Orientasi Manajemen Kepala Madrasah.

2. Orintasi Peningkatan Kuriklum (KTSP).

3. Penguatan Keiembangaan Madrasah.

4. Orentasi Penyelenggaran Madrasah Tsanawiyah Swasta.

5. Pemberian Bantuan kepada Guru yang berprestasi.

6. Bantuan Belajar Dikdas.

7. Bantuan Opersional Sekolah 
Selain itu, terdapat pula program sertifikasi guru dan pemberian insentif kepada guru-guru honor di seluruh madrasah. Program sertifikasi ini pada kecamatan Mambi masih belum terlaksana disebabkan ketidakjelasan DIKNAS dan Kandepag kabupaten, program pemberian intensif kepada guru-guru honorer telah dioperasionalkan dengan memberikan insentif kepada guru-guru honor sebesar Rp. 200.000, per orang khusus guru-guru di bawah naungan DEPAG yang ditangani langsung oleh pihak KANWIL provinsi.

Program-program pendidikan secara nyata telah menjadi perhatian bersama, berbagai hal terkait dengan proses pembelajaran sebagaimana layaknya sebuah pendidikan begitu banyak mengalami kendala. Tugas berat dirasakan oleh pihak Kanwil Depag Sulbar dalam mengatasi hal-hal seperti dari segi SDM kurangnya guru agama, fasilitas sekolah yang tidak memadai dan terkadang sekolah-sekolah formal tersebut tidak tersentuh dikarenakan medan yang terlalu berat untuk menjangkau sekolah. Secara bertahap upaya-upaya yang telah dilakukan adalah: pertama, melakukan pendataan terhadap sekolah-sekolah, terkait dengan ketersedian guru-guru termasuk guru agama di sekolah-sekolah MI, MTs, dan MA. Kedua, menempatkan guru-guru mengaji di masjid-masjid, ketiga, melengkapi fasilitas sarana dan prasaran pembelajaran di sekolah, hal ini baru sebagian kecil sekolah.

\section{Kebijakan pemerintah terhadap aktivitas keagamaan}

\section{a. Aktivitas keagamaan umat Islam}

Bentuk implementasi kebijakan Depag Sulbar terhadap daerah konflik diantaranya adalah penyuluhan dan sekaligus pembinaan terpadu berkenaan dengan keluarga sakinah, pekawinan, zakat wakaf dan badan sosial dan infaq, pembinaan dilakukan dua sampai tiga kali dengan kunjungan ke lokasi-lokasi dalam wilayah Sulawesi Barat, termasuk kunjungan ke kecamatan Mambi. Kegiatan-kegiatan keagamaan yang akan di lakukan di sosialisasikan dan informasikan melalui media Radar Sulbar untuk di sosialisasikan ke masyarakat tentang program-program Depag, kerjasama ini dilakukan agar masyarakat mengetahui kegiatan-kegiatan tersebut.

Pihak Kanwil Departemen Agama Sulbar telah memiliki program pembinaan di daerah-daerah tidak terkecuali daerah Mamasa, diantaranya adalah pengangkatan tenaga KUA di kecamatan, penghulu, perbaikan dan renovasi kantor KUA, lomba keluarga sakinah, dan beberapa lomba dalam meningkatkan peran masyarakat dalam melaksanakan aktifitas keagamaan, dll. 
Khusus di kecamatan Mambi Program Departemen Agama tersebut telah diterapkan dengan renovasi dan pembangunan kantor KUA dan kantor KUA telah ditempati kurang lebih satu tahun dan disertai pengangkatan pegawai administrasi dan penghulu sebanyak 9 orang. Sesuai peranannya KUA kecamatan Mambi dalam pelayan kepada masyarakat cukup berperan dalam pembinaan kepada masyarakat seperti dalam pelayanan pernikahan, rujuk, pembinaan keluarga sakinah, pembinaan terhadap masjid-masjid, zakat dan lainlain.

\section{b. Aktivitas keagamaan umat Kristen}

Setelah terjadi konflik dan kerusuhan, umat kristiani mengungsi ke beberapa desa di luar kelurahan Mambi diantaranya desa Rantepalado, Minaga, karakeang, tomba, Saludenginga, Saluassing, dan Peba serta sebagian lagi mengungsi ke daerah di luar kecamatan Mambi seperti Mamuju, Mamasa dan daerah-daerah lain. Secara otomatis di kecamatan Mambi pasca konflik penduduk yang menetap adalah umat Islam. Kondisi ini membuat umat Kristen belum menampakkan tanda-tanda untuk kembali ke kelurahan Mambi hal ini ditandai dengan tidak ditempatinya rumah-rumah umat Kristen yang masih kosong di tinggal mengungsi. Di lokasi-lokasi pengungsian ini aktivitas kebaktian di gerejatetap terjadwal sesuai program pihak gereja dan tidak ada hambatan sama sekali. Maka praktis tidak terjadi interaksi antara kedua belah pihak yang pro (di dominasi pihak kristen) dan kontra (didominasi pihak Islam). Kedua belah pihak ini belum menampakkan interaksi dan kerjasama dalam berbagai hal. Dengan mengungsinya umat Kristen tersebut maka secara otomatis gereja terbesar di kecamatan Mambi yaitu Gereja Toraja Mamasa (GTM) tidak berfungsi disebabkan jemaat dan pendetanya turut mengungsi.

\section{Implementasi pendidikan agama dan keagamaan di kecamatan Mambi.}

Urgensi pendidikan agama dan keagamaan sangat dirasakan oleh masyarakat kecamatan Mambi khusunya, baik pendidikan agama di sekolah maupun kehidupan keberagamaanya. Untuk lebih mengetahui in put, proses, out put dan pelaksanaan pendidikan agama di sekolah maka sekolah yang di jadikan sampel adalah MTs DDI 0017 Mambi, dengan pertimbangan bahwa madrasah ini merupakan madrasah satu-satu untuk tingkat pertama/ tsanawiyah yang ada di wilayah kecamatan Mambi yang keberadaan turut memberikan nuansa dalam menumbuh kembangkan generasi muda di kecamatan Mambi. 


\section{Implementasi pendidikan Agama pada Madrasah Tsanawiyah DDI 0017 Mambi.}

Sejarah berdiri, MTs DDI 0017 Mambi berdiri pada tanggal 1 Januari 1968 yang berinduk pada MTS Negeri Tinambung. Dewasa ini MTs DDI Mambi telah melepaskan diri dan berdiri sendiri berstatus diakui dengan nomorNSS/ NPSN : $212131809017 / 210160$. MTs DDI 0017 beralamat di jalan Poros Sendana Mambi, keberadaan madrasah ini pada awalnya merupakan sekolah yang sangat diminati oleh masyarakat Mambi khususnya yang menginginkan anaknya belajar di madrasah. Keberadaan MTs DDI 0017 Mambi yang bernaung dalam yayasan DDI dengan lembaga pembina Departemen Agama dengan mempunyai misi "mewujudkan manusia yang unggul, berilmu, cerdas dan terampil" dan visi "melaksanakan pembelajaran dan penilaian yang efektif". Pasca konflik berbagai perubahan terjadi terkait dengan proses PBM pada madrasah ini. Selama masa konflik antara tahun 2003-2004 proses pembelajaran dan aktivitas akademik tidak berjalan, ini disebabkan masyarakat Mambi khususnya orang tua siswa memilih untuk mencari tempatyang aman di luar kota Mamabi. Keberadaan siswa-siswa dari MTs DDI Mambi pasca konflik yang terjadi berangsur-angsur kembali setelah kondisi kota Mambi kembali normal. Tetapi sampai penelitian ini dilakukan siswa-siswa MTs DDI masih ada yang belum kembali. Ketika melakukan konfirmasi baik ke pihak Departemen Pendidikan (DIKNAS Propinsi) dan Kanwil Depatemen Agama siswa-siswa yang masih terdaftar tetapi belum kembali tetap di masukkan datanya sampai siswa yang bersangkutan secara resmi mengundurkan diri untuk pindah sekolah. Keberadaan siswa-siswa yang belum kembali ke MTs DDI ini sebagian merupakan siswa titipan di sekolah-sekolah tempat pengungsian.

Sarana dan prasarana fisik, MTs DDI 0017 Mambi dari segi ketersedian sarana dan prasarana fisik sangat minim, meskipun secara fisik prasarana berupa bangunan sekolah sudah permanen tetapi dari fasilitas pembelajan belum didukung dengan berbagai fasilitas pembejaran. Status kepemilikan tanah adalah hak milik dengan luas sekolah $1409 \mathrm{~m}^{2}$, dan luas bangunan $327 \mathrm{~m}^{2}$. Memiliki ruang kepala sekolah, ruang guru, dan ruang tamu yang menyatu, WC, lapangan olah raga, meja dan kursi siswa, rak/lemari buku 4 buah, buku paket 50 buah, buku penunjang 30 buah, dan buku bacaan 50 buah.

Keadaan guru dan murid, MTs DDI 0017 Mambi memiliki tenaga pendidikan 16 orang dengan status guru tidak tetap yang berasal dari guru SMA 1 Mambi dan Guru SMP 1 Mambi, diantaranya 2 orang sebagai tenaga 
inistrasi dan masing-anasing sataa $\mathrm{mmg}$. kepslta sdkdyk, mafkOl ikepala olah, sekretaris, bemdahara. pamjaga sffasbli Jam jfanog taiksinya adalah .lasai guru.

f .alar hpbLang kpprwtMtikam gpnra Itf R mm Manrrthii .ttiftaliafti (iftwrii 1 \$ orang 9 orang diantararaya adalah bespeediidiiil Lsm! sanfanna ((Si) (Sam 5 (aisaa^sffifiloma II dan 2 orang SMA sebagai temaga admnristfcasi JadSi itiis^feat fonaHiifoni ttenaga

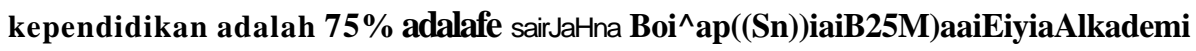
(diploma) dengan $70 \%$ latar bdakang $\mathbf{~ m M U B d " m i ~ m c a a i a i ~ ( d f e m p H i ~ r a ` a p d l a j a r a n ~}$ yangdiajarkan.

Jumlah rombongan bebjjar sdbamrplk 3 Ikeflas dkmgam jpn«WB smm. uuntuk tahun ajaran 2007-2008 sebanyak 72 siswa, ttatt ttsibril $L$

T a W 1

Jumlah siswa MTs DIM 0017 Mammy nnnainDanattJefflisMann^^

\begin{tabular}{|c|c|c|c|c|}
\hline \multirow{2}{*}{ NO } & \multirow{2}{*}{ KHLAS } & \multirow[b]{2}{*}{ L A B 4 J U } & & \multirow[b]{3}{*}{077} \\
\hline & & & \multirow[b]{2}{*}{$*$} & \\
\hline 1 & I & ID & & \\
\hline 2 & II & $1 \$$ & & $m$ \\
\hline 3 & III & IS & D3 & \\
\hline \multicolumn{2}{|c|}{ JUMLAH } & 44 & $2 »$ & $7 \mathrm{Z} 2$ \\
\hline
\end{tabular}

Swnber Data: MB DDI WM7 Mambii

Jumlah siswa-siswa pada tabeO «fi atlas mmanyineam sasmat ${ }^{\wedge}$ osma. yang terdaftar pada madrasah, rneski pada Ikamyadaaii^a nr\&asti sadia siiswai j/atng fodki m kembali atau merupakan siswa tihtiipami pada \$dMa\#h-sdfe»ilaiiln cffitompat pengungsian, dan ketiga tiba saateya uqjänn allinikr aikaui fesrllamg\$ini>s£ iMWJWa-sisvva tersebut akan kembali memgsks $A$ proses pOTfcdkjjamaBn.. Siswai-siiswai paafta ttabe I tersebut di atas merupakan sisma-siiswa ysamg faasafl darii dtearafiKdiaaEah di sekhar wi la y ah Mambi dan beberapa $£ m M m m s \$ m$ nmisraipATOgHmiftBlïam atari iuiar kecamatan Mambi.

Perkembangan dari jnnmllah siswa pada MTs EMD WW Mamflxi atorii4ttaiiun tcrakhirvaitu tahun 2004-2007, dapattdiBhat paiattrfsdlZ. 
Proses pembelajaran yang dilakukan pada Madrasah adalah merujuk pada Kurikulum Tingkat Satuan Pelajaran KTSR kurikulum ini sudah di sosialisasikan pada pembelajaran, dan secara keseluruhan guru-guru madrasah telah mendapat sosialisasi tentang KTSP Sebelum penggunaan KTSP terlebih dulu menggunakan kurikulum 1994 dan Kurikulum Berbasis Kompetensi (KBK 2004) dimana memiliki perbedaan dari segi materi yang lebih padat.

Sistem pembelajaran yang dipergunakan pada proses pembelajaran menggunakan model-model pembelajaran dengan metode ceramah, demonstrasi, diskusi, eksperimen, penugasan dan menggunakan lingkungan madrasah sebagai proses pembelajaran.

Sistem evaluasi, MTs DDI 0017 Mambi dalam upaya meningkatkan kualitas pendidikan, berbagai upaya dilakukan seperti melakukan persiapan pembelajaran yang berperanan penting dalam proses belajar mengajar. Beberapa hal yang terkait dengan persiapan pembelajaran yaitu Rencana Pelaksanaan Pembelajaran (RPP), buku teks (buku pegangan guru) dan kesiapan guru dan siswa dalam melakukan pembelajaran. Evaluasi dilakukan sebagai upaya untuk mengetahui pengetahuan dan pemahaman siswa terhadap materi-materi yang telah diajarkan. Evaluasi yang diberikan oleh guru adalah evaluasi formatifdan evaluasi sumatif. Hal ini dilakukan sebagai upaya untuk mengukur tingkat keberhasilan siswa dalam memahami materi yang diperoleh dan bagi guru merupakan evaluasi terhadap kemampuan guru dalam memberikan materi pelajaran, tetapi yang terpenting adalah kesiapan sarana dan media pembelajaran yang sangat mendukung. Kendala-kendala inilah yang dirasakan oleh guru-guru MTs DDI 0017 Mambi yakni minimnya sarana dan fasilitas pembelajaran.

Program kegiatan yang menunjang kurikuler yang ditetapkan oleh pihak madrasah dan setiap siswa dituntut untuk mengikutinya dengan tujuan untuk meningkatkan pengetahuan, minat, dan bakat dan kreativitas siswa. Diantara program-program tersebut adalah: pengembangan minat baca tulis Alquran, kaligrafi, ceramah dan khutbah, olah raga dan pengembangan bidang pertanian. Sementara program tindak lanjut yang di tetapkan pihak madrasah adalah membudayakan bahasa Arab dalam lingkungan sekolah. Dalam bidang kesenian program yang telah ditetapkan adalah qasidah rebana, tadarrus dan tilawah.

Sebagai bentuk pertanggung jawaban terhadap aktivitas pembelajaran yang dilakukan pada MTs DDI 0017 Mambi, selama ini dilakukan per tiga bulan dalam satu tahun. Khusus wilayah Mambi pertanggungjawaban dilakukan langsung ke Kanwil Departemen Agama provinsi Sulawesi Barat, Kabid 
Mapenda Islam dan seluruh Kasi di Mapenda, tanpa melalui Kandep Kabupaten. Proses ini juga yang merupakan dampak dari konflik yang terjadi di kecamatan Mambi yaitu hilangnya sistem pemerintahan khusunya Kandep tingkat kabupaten di sebabkan adanya pihak yang pro dan kontra pemekaran.

\section{Implementasi Pendidikan Keagamaan Pada Masyarakat di Kecamatan Mambi.}

Aktivitas keberagamaan masyarakat kecamatan Mambi pada umumnya tidak mengalami kendala dan berjalan sebagaimana biasanya. Demikian halnya kegiatan-kegiatan yangberkaitan dengan peringatan-peringatan hari-hari besar Islam seperti perayaan Maulid Nabi Muhammad SAW. Hati-hari besar Islam ini diperingati dan di rayakan, ini dilakukan setiap tahun dengan cara bergiliri dari masjid ke masjid seperti halnya peringatan maulid Nabi Muhammad SAW tahun 1429 Hijriah yang diperingati di Masjid al-Ihsan. Bagi masyarakat kecamatan Mambi rutinitas di bidang keagamaan tetap berjalan baik seperti pelasanaan shalat lima waktu, sahalat jumat, shalat tarwih pada bulan Ramadhan dan shalat id. Di samping kegiatan-kegiatan tersebut kegiatan lain yang turut mewarnai ativitas kegamaan masyarakat di kecamatan Mambi diantaranya:

\section{a. Majelis Taklim}

Di kecamatan Mambi terdapat dua kelompok majlis taklim, yaitu Ummahatus Shalihin dan al-Ihsan. Kedua kelompok ini memiliki aktivitas yang rutin dalam melakukan pengajian-pengajian.

Majelis taklim Ummahatus Shalihin, keberadaannyajauh sebelum konflik terjadi dan kepengurusan majlis taklim ini pimpimpin oleh Suhartina Dewi dengan jumlah pengurus sebanyak empat orang dan memiliki anggota +30 orang. Pelaksanaan pengajian biasanya di lakukan ba'da ashar di rumah-rumah anggota majelis taklim yang bersedia dan dilakukan secara bergilir dari rumah ke rumah. Pada awalnya pengajian dilakukan pada hari kamis tetapi dewasa ini kegiatan ini sudah tidak ditetapkan harinya.

Dalam pengajian-pengaj ian yang dilakukan materi-materi yang di berikan sangat beragam dan bervariasi tergantung dari para ustaz atau pemateri. Biasa materi yang diberikan adalah materi dasar-dasar agama, misalnya fiqhi tentang bagaimana bersuci yang benar, shalat, mengurus jenazah serta beberapa materi yang berhubungan dengan kehidupan sehari-hari, Muamalah, toleransi, danjuga belajar membaca A1-Qur'an dengan metode Iqra'. Hal ini diberikan oleh pemateri karena masih banyak masyarakat yang masih buta aksara Alquran. 


\section{b. Pengajian Umum dan pengajian Khusus}

Pengajian Umum, kelompok pengajian umum adalah kelompok pengajian yang anggotanya merupakan gabungan dari seluruh lapisan masyarakat baik laki-laki, perempuan, dewasa maupun anak-anakyang pelaksanaanyadi lakukan di masjid Taqwa kecamatan Mambi, jadwal pelaksanaannya adalah sore hari yaitu pada hari kamis setelah usai aktivitas di pasar baik yang berjualan maupun sebagai pembeli, hari kamis merupakan hari pasar di kecamatan Mambi dan biasanya para penggunjung yang datang dari luar kecamatan Mambi berkesempatan untuk mengikuti pengajian tersebut. Jumlah jamaah pengajian biasanya +70 orang.

Keagiatan lain yangjuga menjadi aktifitas rutin pada masjid Taqwa adalah membinaTPA/TKA dengan dua kelompok pengajian yaitu pengajian Alquran dan kelompok pengaj ian Iqra'. Masing-masing kelompok memiliki santri yang cukup banyak. Untuk kelompok pengajian Alquran memiliki santri 34 orang (laki-laki 18 orang dan perempuan 16 orang) sementara kelompok pengajian Iqra' memiliki santri 85 orang (laki-laki 37 orang dan perempuan 48 orang). TKA/TPA masjid Taqwa telah melakukan wisudawan dan wisudawati untuk tahun 2007.

Pengajian Khusus, pada kelompok pengajian khusus sangat berbeda dengan kelompok pengajian umum, pada kelompok ini dikhususkan bagi pembinaan kader-kader dai (juru dakwa). Kelompok ini juga dikenal dengan istilah "Tabiyah Khusus". Keanggotaan kelompok ini terdiri dari 10 orang untuk tiap kelompok dan pengajiannya dilakukan tiga kali seminggu. Materi yang diajarkan biasanya adalah tentang keimanan, fiqhi, tauhid, muamalah, dan lainlain. Sementara metode yang biasa digunakan dalam proses pembelajaran adalah ceramah, tanyajawab, diskusi serta praktek.

Beberapa kendala-kendala dalam pelaksanaan pengaj ian-pengajian, dewasa ini diantaranya:

- Adanya sebagian masyarakat yang masih merasa trauma dengan konflik yang pernah terjadi, sehingga kadang hanya ada suara yang agak keras, mereka sudah kaget dan cemas.

- Masih adanya anggota kelompok pengajian yang belum kembali dari pengungsian.

- Masyarakat belum sepenuhnya merasa aman untuk melakukan berbagai aktivitas. 
Selain aktivitas dalam bentuk kelompok pengajian, aktivitas lain yang dilakukan oleh tokoh-tokoh agama masyarakat kecamatan mambi yaitu pembinaan bagi kaum Muallaf, pembinaan ini pada awalnya rutin dan terjadwal namun pacsa konflik kegiatan ini sedikit berkurang terutama dalam hal kunjungan dan silaturrahim dengan kaum muallaf. Kebanyakan para muallaf $\backslash m$ berasal dari pemeluk agama Kristen dan sebagian adalah penganut animisme yang oleh masyarakat kecamatan Mambi di gelar masyarakat "To Malilling". To Malilling diartikan sebagai "orang gelap". Masyarakat To malilling pada umumnya menempati wilayah jauh di pedalaman Mambi biasanya mendiami wilayah gunung. Keberadaan komunitas To Malilling dewasa ini sudah menyebar keberbagai tempat dan memiliki komunitas yang tidak sedikit. Demikian halnya proses pengislaman sering dilakukan oleh tokoh-tokoh agama kecamatan Mambi. Salah satu desa yang memiliki beberapa orang mullqf 'adalah desa Sondang Lajuk, central aktivitas para muallaf desa Sondang Lajuk adalah di masjid Nurul Iman.

\section{PENUT UP}

\section{A. Kesimpulan}

1. Konflik yang terjadi di kecamatan Aralle, Tabulahan, dan Mambi dipicu oleh pro-kontra penggabungan wilayah tiga kecamatan tersebut ke kabupaten Mamasa provinsi Sulawesi Barat berdasarkan terbitnya Undang-undang No 11 tahun 2002 tentang pembentukan kebupaten Mamasa dan Palopo, Puncak konflik di wilayah Aralle, Tabulahan dan Mambi pecah padatanggal 29 September 2003. Peristiwa kerusuhan kembali terjadi akhir Juli sampai awal Agustus 2004. Terakhir, kerusuhan di kecamatan Aralle terjadi pada hari Jumat, 16 Oktober 2004 dan berlanjut hingga Selasa, 19 Oktober 2004 dan meluas hingga ke kecamatan Mambi. Beberapa dampak akibat konflik yang terjadi di kecamatan Mambi yang berakibat pada dunia pendidikan maupun aktivitas keagamaan adalah tidak berfungsinya sistem Pelaksanaan Administrasi Pendidikan di tingkat kabupaten, berkurangnyajumlah guru, berkurangnyajumlah siswa, dan terjadinya arus pengungsian.

2. Dalam rangka meningkatkan dan memperdayaan sekaligus pengembangan Pendidikan agama dan keagamaan, pemerintah (Departemen agama) bidang Mapenda hendaknya membuat kebijakan terkait dengan: 1) Pemerataan pendidikan, 2) Peningkatan Mutu Pendidikan, 3) Efektifitas dan efisiensi penyelenggaraan pendidikan, meialui upaya diantaranya: pertama, melakukan pendataan terhadap sekolah-sekolah, terkait dengan ketersedian 
guru-guru termasuk guru agama di sekolah-sekolah MI, MTs, dan MA. Kedua, menempatkan guru-guru mengaji di masjid-masjid, ketiga, melengkapi fasilitas sarana dan prasaran pembelajaran di sekolah/madrasah.

3. Implementasi pendidikan agama dan keagamaan di kecamatan Mambi secara umum tidak mengalami kendala dalam proses pembelajaran baik pada sekolah umum maupun pada madrasah-madrasah. Demikian halnya terhadap aktivitas keagamaan masyarakat yang tetap berjalan, seperti majelis taklim, pengajian-pengajian dan aktivitas keagamaan lainnya.

\section{B. Rekomendasi}

Upaya perdamain dan penataan harus terus dilakukan oleh pemerintah dan berbagai pihak, sebagai upaya mencegah munculnya konflik baru. Seperti menjaga perdamaian dan menjaga keberlangsungan perdamaian dan memfokuskan penyelesaian masalah melalui pengembangan hubungan yang baik di antara masyarakat yang terlibat konflik baik yang pro maupun yang kontra Mamasa. Ketiga, pengembangan wawasan multikultural melalui pertemuan, diskusi dan dialog, harus terus digalakkan.

Kebijakan-kebijakan yang telah ditetapkan harus terus diupayakan dan dimplementasikan terutama daerah yang sulit dijangkau seperti daerah-daerah terpencil. Kenyataan ini perlu mendapat perhatian terutama dari pihak pemerintah daerah, Kanwil Departemen Agama Sulbar maupun pihak pemerintah daerah untuk memberikan pembinaan, perhatian dan bantuan yang dibutuhkan agar madrasah-madrasah ini dapat berkiprah dalam meningkatkan pendidikan.

1 Aktivitas pendidikan agama dan keagamaan di kecamatan Mambi perlu mendapat perhatian khusus dalam hal peningkatan, baik pihak Diknas maupun Depag, terkait dengan aktivitas proses pembelajaran seperti ketersediaan tenaga pengajar yang mengalami kekosongan terutama guru pendidikan agama Islam, keberadaan siswa yang tidak menentu, dan ketersediaan fasilitas yang minim.

\section{DAFTAR PUSTAKA}

A. Azizy, Qodri dalam Drs. H. Abdul Hamid M.Ed dan Drs.H.A.Kadir Jaelani M.Pd (Ed), 2003, Profesionalisme Pengawas Pendais, Jakarta, Departemen Agama RI Direktorat Jenderal Kelembagaan Agama Islam.

Achmad, Firdaus, 2005, Potret Kerukunan Umat Beragama di Indonesia, Jakarta, Harmoni (Puslitbang Kehidupan Beragama, Badan Litbang dan Diklat Keagamaan Jakarta). 
Budiman, dalam A.W Widjaja, 1986, Manusia Indonesia, Individu Keluarga Dan Masyarakat, Jakarta, Akademika Pres Sindo.

E. Toeke, Idrus, 2006, Menyatukan Pandangan Dalam Semangatlmani Membangun Maluku Bersaudara, Ambon, Majelis Ulama Indonesia Provinsi Maluku.

Narwoko, J. Dwi dan Bagong Suyanto, 2006, Sosiologi Teks Pengantar dan Terapan, Jakarta: Kencana.

Nuryanis dan Romli, 2003, Pendidikan Luar Sekolah, Jakarta, Departemen Agama RI Direktorat Jenderal Kelembagan Agama Islam.

Arraiyyah, Hamdar, dan Nahar Hahrawi, 2005, Kerukunan Umat Beragam Pasca Konflik, Jurnal Al Qalam, Makassar: Balai Penelitian dan Pengembangan Agama Makassar.

Idham, 2008, Proses dan Dinamika Konflik(Studi Tentang Konflik Sosial di Kecamatan Aralle, Tabulahan, dan mambi (ATM) Sulawesi Barat, Disertasi PPs. UNM.

Lauer, Robert H, 2001, Perspektif Tentang Perubahan Sosial, cet III, Jakarta, PT. Rineka Cipta.

Liliwari, Alo, 2005, Prasangka \& Konflik, Komunikasi Lintas Budaya Masyarakat Multikultur, Yogyakarta, FKIS Yogyakarta.

Lubis, Ridwan, Ed, 2005, Meretas Wawasana \& Praksis Kerukunan Umat Beragama Di Indonesia, Jakarta, Puslibang Kehidupan Beragama Badan Litbang dan Diklat Keagamaan Jakarta.

Pruitt, Dean G, and Jeffrey Z. Rubin, 2004, Teor.i Konflik Sosial, cet I, Jakarta, Pustaka Pelajar.'

Saridjo, Marwan, 1998, Bunga Rampai Pendidikan agama Islam, Jakarta, CV. Amissco Departemen Agama RI, Direktorat Jenderal Pembinaan Kelembagaan Agama Islam.

Shaleh, Abdul Rahman, 2006, Pendidikan Agama dan Pembagunan Watak Bangsa, Jakarta, PT. Raja Grapindo Persada.

Soemantri, RHAS, 1986, Pedoman Pelaksanaan Pendidikan Agama Islam pada SD, Cet.IV, CV. Multiyasa \& Co, Departemen Agama RI Direktorat Jenderal Pembinaan Kelembagaan Agama Islam, Proyek Pembinaan Pendidikan Agama Pada Sekolah Umum, Jakarta. 1986.

Tafsir, Ahmad, 1994, llmu Pendidikan Dalam Perspektif Islam, cet.II, Bandung, PT Remaja Rosda Karya.

Tajuddin, M. Syarif, dkk, 2004, MenelisikSejarah Mandar, Ditelusuri lewat situs internet http://www.polewalimandarkab.go.id/indekx.php?ienis=content $\& \mathrm{id}=202$ 